Darko Lazarov ${ }^{1}$

Mitko Kocovski ${ }^{2}$
JEL: F14, F40

DOI: 10.5937/industrija45-12015

UDC: $339.564(497.17)$

330.341.1:669.1/.8

Original Scientific Paper

\title{
Empirical analysis of Macedonian export structure: the role of metal industry ${ }^{3}$
}

\author{
Article history: \\ Received: 10 October 2016 \\ Sent for revision: 17 November 2016 \\ Received in revised form: 21 January 2017 \\ Accepted: 22 January 2017 \\ Available online: 5 April 2017
}

\begin{abstract}
The paper investigates the Macedonian export structure and export performance by using several indexes: product complexity, export sophistication, export diversity, and export ubiquity for the period 1995-2014. The empirical analysis is based on the application of product space methodology (based on network theory) developed by Hidalgo et al. (2007) with data from UN comtrade database. Moreover, the paper analyzes the performance of metal industry and its productivity as one of the biggest exporting sector and investigates its capacity for further product diversification. The estimated results indicate that Macedonian export basket is highly concentrated (the top ten products have nearly half of the total country's export and more than 70 percent of the export goes to several countries) and more importantly the export structure is composed of products with low complexity level. Additionally, the results show that the export structure is less diversified, making the economy very sensitive on the external shocks. On the other side, the analysis of metal industry performance indicates that this industry has comparative advantages $(R C A=2.16)$ and more importantly it has strong capacity for further diversification by building new capabilities for production of more complexed products. So, the suggestion to policymakers in Macedonia is to be created an active industrial policy that will stimulate the structural transformation of metal industry towards products with higher value added.
\end{abstract}

\footnotetext{
${ }^{1}$ University Goce Delchev, Stip, darko.lazarov@ugd.edu.mk

${ }^{2}$ Makstil a.d - Skopje

3 The paper is result of the project entitle "Analysis of production capacity and capabilities for diversification of metal industry in Republic of Macedonia", supported and financed by Macedonian Chamber of Commerce. The paper was presented at ECIN 2016 conference.
} 
Lazarov D., Kocovski M.: Empirical analysis of Macedonian export structure: the role...

Keywords: Export structure and sophistication, economic growth, Macedonia.

\title{
Empirijska analiza izvozne strukture Makedonske ekonomije: uloga metalne industrije
}

\begin{abstract}
Apstrakt: Osnovni je cilj rada analiza izvozne strukture $i$ izvozne performanse makedonske ekonomije na osnovi primene nekoliko relevantnih indeksa: kompleksnost proizvoda, izvozna sofisticiranost, izvozna diverzificiranost i izvozna standardnost. Osim toga, rad analizira sofisticiranost metalne industrije $i$ njen učinak u makedonskoj ekonomija kao jedan od najvećih izvoznih sektora $i$ istražuje njene kapacitete za dalju diverzifikaciju proizvoda. Procenjeni rezultati pokazuju da makedonska izvozna korpa je visoko koncentrisana (prvih deset proizvoda čine skoro polovinu izvoza zemlje $i$ više od 70 odsto izvoza ide u nekoliko zemalja) i što je još važnije, struktura izvoza se sastoji od proizvoda niske dodatne vrednosti. Osim toga, rezultati pokazuju da je struktura izvoza manje diverzifikovana, što ekonomiju prave veoma osetljivu na spoljne šokove. S druge strane, analiza učinka metalne industrije ukazuje da ova industrija ima komparativne prednosti $(K P=2.16) i$ što je još važnije ima jake kapacitete za dalju diverzifikaciju i mogućnosti za proizvodnju više kompleksnijih proizvoda. Dakle, rad predlaže kreatorima ekonomske politike u Makedoniji da kreira aktivnu industrijsku politiku koja će stimulisati strukturnu transformaciju metalne industrije i proizvodnju proizvoda sa većom dodatnom vrednošću.
\end{abstract}

Ključne reči: Struktura izvoza, izvozna prefinjenost, ekonomski rast, Makedonija.

\section{Introduction}

The export-lead-growth empirical literature based on cross-country regression approacj suggests that the long-run growth is driven by the export volume, Thirlwall (1994); Keesing (1967); Krueger (1985). This stream of the growth literature indicates that export activity promotes economic growth regardless the export structure. However, there is debate about the causality between export and growth. The individual country analysis is used to investigation of this issue. The results of the time-series studies of export and growth are a bit ambiguous. Some studies found that there is causal relationship from export to growth, Chow (1987); Darrat (1987); Ahmad et al. (1997); Liu et al. (1997), while others found endogeneity and revesre causality between export and growth indicating that not only export has impact on growth, but in the same time growth leads export, Thornton (1997) Shan \& Sun (1998a); Islam (1998). On the other side, new growth and trade theory indicates that export 
Lazarov D., Kocovski M.: Empirical analysis of Macedonian export structure: the role...

complexity (structure) instead of export volume is a fundamental growth determinant, Hausmann et al. According to these theories countries with more complex and diversified export structure have more ability to grow faster, and vice-versa, Hausmann et al. (2005); Jesus Felipe at el. (2010); Jarreau and Poncet (2012). The paper investigates the Macedonian export structure and it performance using several indexes: 1) export complexity- weighted average of the sophistication level of products exported by the country, 2) export diversity - number of products that country produces and exports with comparative advantages, and 3) export ubiquity - number of countries produce same set of products. The empirical analysis use data from 6-digit Harmonized classification system of ComTrade database for about 5.107 products and apply the product space concept developed by Hidalgo, Klinger, Barabasi and Hausmann, Hidalgo et al. (2007). The results of export structure indicate that Macedonian export basket is highly concentrated (the top ten products have nearly half of the total country's export and more than 70 percent of the export goes to several countries) and composed of standard products which required less specific capabilities. Additionally, the results show that the export structure is less diversified, making the economy very sensitive on the external shocks.

Moreover, the paper analyzes the productivity and complexity of metal industry as one of the dominant industry in Macedonian economy and its capacity for futther diversification. For that purpose, in the empirical work is used reveal comparative advantages (RCA) index to identify the industry position and its capacity to diversify the existing composition by building capabilities for production of new more complexed products, Balassa, B. (1965); Siggell (2007).

According to our information, no studty until now investigate the export structure of individual industries by using product space methodology on 6digit data, so the contribution of the paper is the new insights about the Macedonian export structure with special focus on the metal industry as one of the most important one for Macedonian export. The isights are an objective foundation for better industrial policy towards structural transformation of the economy by supporting the sectors and industries with the strongest potencials and capabilities.

The rest of this paper is organized as follows. In Section 2, we present a theoretical framework of export structure analysis. Section 3 analyzes the export structure of Macedonian economy with special focus on the role of metal industry. In Section 4 we explain the main findings and give several important advices to policymakers how to improve and diversify the Macedonian export as important step in fostering economic growth. 
Lazarov D., Kocovski M.: Empirical analysis of Macedonian export structure: the role...

\section{Theoretical framework of export structure analysis}

For the purpose of export structure analysis it is used several indexes which describe home many products are exported with the comparative advantage by the country, products sophistication and the structure of country's export basket (export complexity). These indexes are: 1) export sophistication index (EXPY) - the productivity and complexity level of products that composed a country's export basket; 2) export diversification index - the absolute number of products that a country produces and exports by comparative advantages among the total set of export products.

\subsection{The "product space" concept}

A country's ability to start production of new products depends on whether the set of existing capabilities necessary to produce these products (human and physical capital, the legal system, institutions, etc.) can be easily redeployed for the production and export of new products. These existing capabilities reflect the package that the country produces and exports with comparative advantage, Hausmann, 2006. For example, it is probably easier for a country that exports T-shirts to add shorts to its export basket than to add smart phones. On the other hand, it is very likely that a country that exports basic cell phones has the capabilities to add smart phones to its export basket. This implies that it is easier to start producing a "nearby" product (in terms of required capabilities to export it successfully) than a product that is "far away," which requires capabilities that the country probably does not possess, Hidalgo et al. (2007; 2009). The different circles represent products (a total of 779). The size of the circles is proportional to their share in total world trade. The lines linking the circles represent the proximity between the products classified in different industries and sectors. Proximity in this context is not a physical concept; rather, it measures the likelihood that a country exports a product given that it exports another one. The rationale is that if two goods need similar capabilities, a country should show a high probability of exporting both with comparative advantage.

It is obvious that the product space is highly heterogeneous. Moresophisticated products are located in a densely connected core and they are close-by to others (because they require similar capabilities), while some others are located in a sparse area of a product space (less sophisticated products occupy a less-connected periphery). In the first case, it is easy to jump from one product into another one with small fixed cost, while in the second case it is difficult and too much costly. The core of the product space (the area with many products close by) contents chemicals, machinery, and metal products. The periphery consists of petroleum, raw materials, tropical 
Lazarov D., Kocovski M.: Empirical analysis of Macedonian export structure: the role...

agriculture, animal products, cereals, labor intensive goods, and capital intensive goods (excluding metal products), Hidalgo (2009).

Figure below shows the product space.

Figure 1. The Product Space

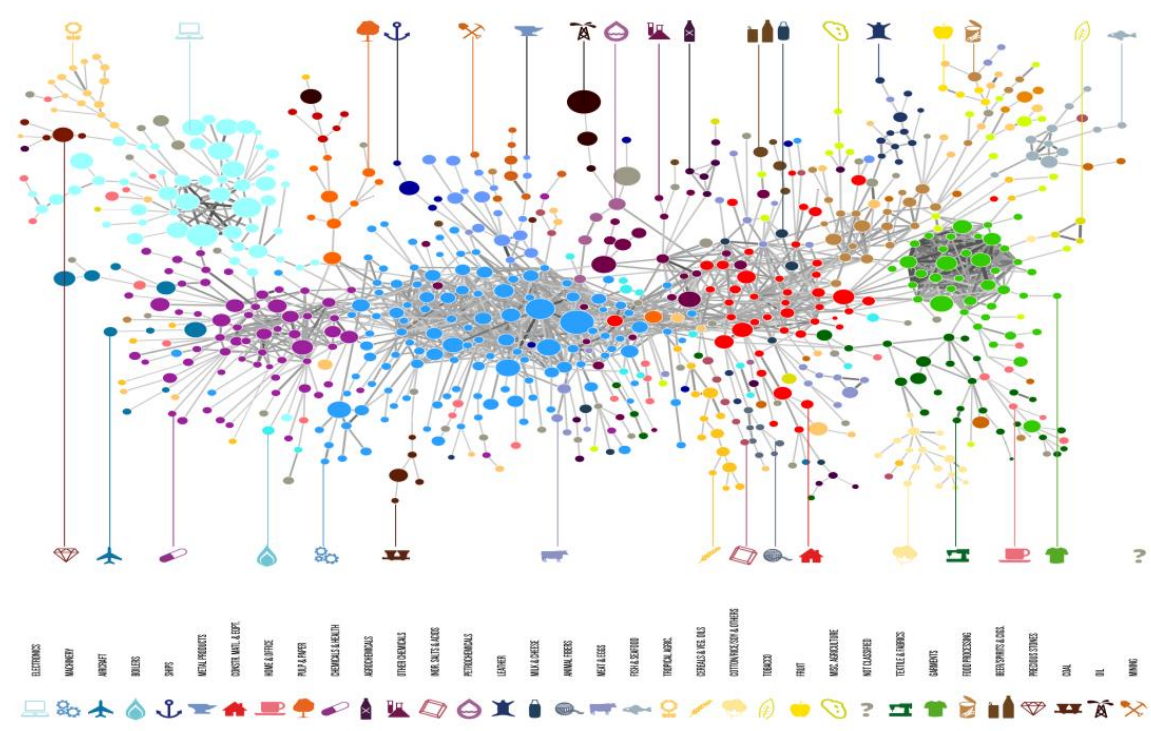

Source: Hidalgo et al. (2007)

\section{Empirical analysis of Macedonian export structure}

Macedonian export volume has increasing trend form 956 million dolars in 1996 to 5.376 million dollars in 2014 . The positive increasing trend has also been recorded in export relative to GDP (from $28 \%$ in 1996 to $48 \%$ in 2014). The exception of these positive trends are 2009, 2010 and 2012 when the export has decreased by $29.5 \%, 20.5 \%$ and $9.5 \%$, respectively, primarily as a result of the negative effects from the global economic crisis. 
Lazarov D., Kocovski M.: Empirical analysis of Macedonian export structure: the role...

Figure 2. Macedonian export volume (mill. dollars) and export relative to GDP

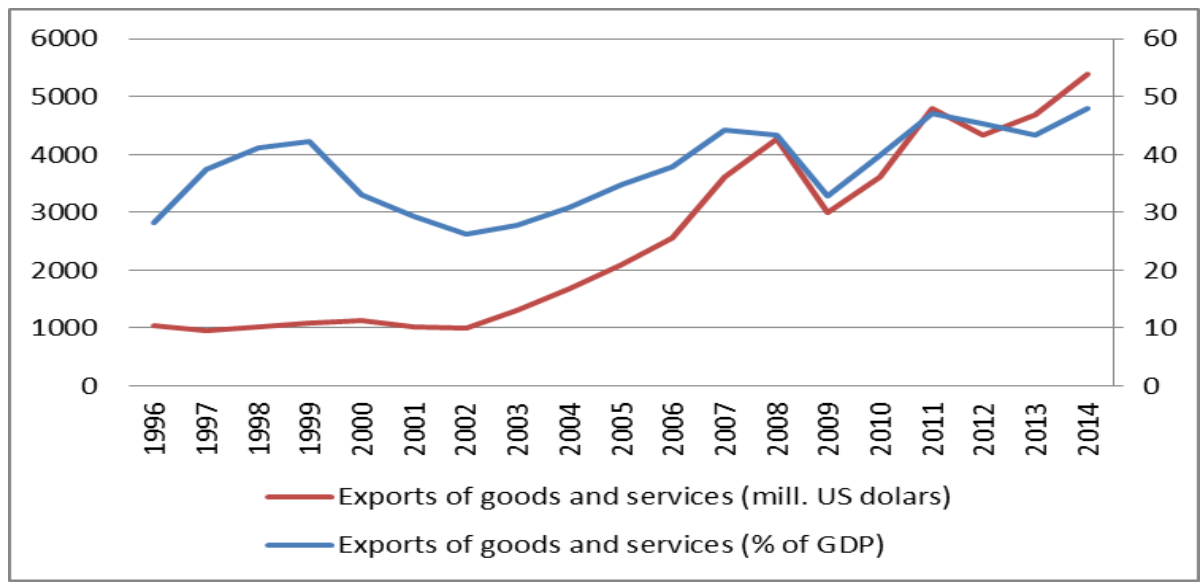

Source: Authors' calculation based on ComTrade database

In the table below are reported the top ten products with highest relative share in Macedonian export in 2014. The data show that the ten products have nearly half of the total country's export indicating that the Macedonia export structure is very concentrated.

Table 1. Top ten exported products in 2014

\begin{tabular}{|c|c|c|c|c|}
\hline$\#$ & $\begin{array}{l}\text { Product } \\
\text { code }\end{array}$ & Product name & $\begin{array}{c}\text { Share, } \\
\%\end{array}$ & $\begin{array}{l}\text { Export } \\
\text { value, } \\
\text { US \$ }\end{array}$ \\
\hline 1 & 381512 & $\begin{array}{l}\text { Supported Catalysts With Precious Metal or Its } \\
\text { Compounds as Active Substance }\end{array}$ & $18 \%$ & 976930402 \\
\hline 2 & 842139 & $\begin{array}{c}\text { Other Filtering or Purifying Machinery and } \\
\text { Apparatus for Gases }\end{array}$ & $7.70 \%$ & 423920749 \\
\hline 3 & 720260 & Ferronickel & $5.20 \%$ & 286257633 \\
\hline 4 & 854430 & $\begin{array}{l}\text { Ignition Wiring Sets \& Other Wiring Sets, for } \\
\text { Vehicles, Aircraft or Ship }\end{array}$ & $3.70 \%$ & 203850625 \\
\hline 5 & 870210 & $\begin{array}{l}\text { With compression-ignition internal combustion } \\
\text { piston engine (diesel or semi-diesel) }\end{array}$ & $3.30 \%$ & 182252711 \\
\hline 6 & 240110 & Tobacco (Not Stemmed) & $2.60 \%$ & 144918679 \\
\hline 7 & 381590 & $\begin{array}{c}\text { Reaction Initiators, Reaction Accelerators, } \\
\text { Catalytic Preparations }\end{array}$ & $1.90 \%$ & 106490107 \\
\hline 8 & 720221 & $\begin{array}{l}\text { Ferrosilicon Containing by weight more than } 55 \\
\text { percent of silicon; silicon content }\end{array}$ & $1.70 \%$ & 93785959 \\
\hline 9 & 620520 & Men's or Boys' Shirts, of Cotton & $1.70 \%$ & 92813880 \\
\hline 10 & 853710 & $\begin{array}{c}\text { Bases for Electric Control or the Distribution, Not } \\
\text { Exceeding } 1,000 \mathrm{v}\end{array}$ & $1.60 \%$ & 86401780 \\
\hline
\end{tabular}

Source: Authors' calculation based on ComTrade database 
Lazarov D., Kocovski M.: Empirical analysis of Macedonian export structure: the role...

The date indicates that the most dominant products in Macedonian export basket in 2014 are: Reaction and Catalytic products $(\$ 1,09 B)$, Centrifuges $(\$ 425 \mathrm{M})$, Ferroalloys $(\$ 383 \mathrm{M})$, Insultaed wire $(\$ 255 \mathrm{M})$ and Non-knit women's suits $(\$ 282 \mathrm{M})$. Additionally, the analysis indicates that Macedonian export basket is highly concentrated (the top ten products have nearly half of the total country's export and more than 70 percent of the export goes to several countries) and composed of low complexed products.

The whole export structure is presented in the Figure below.

Figure 3. Macedonian export structure in 2014

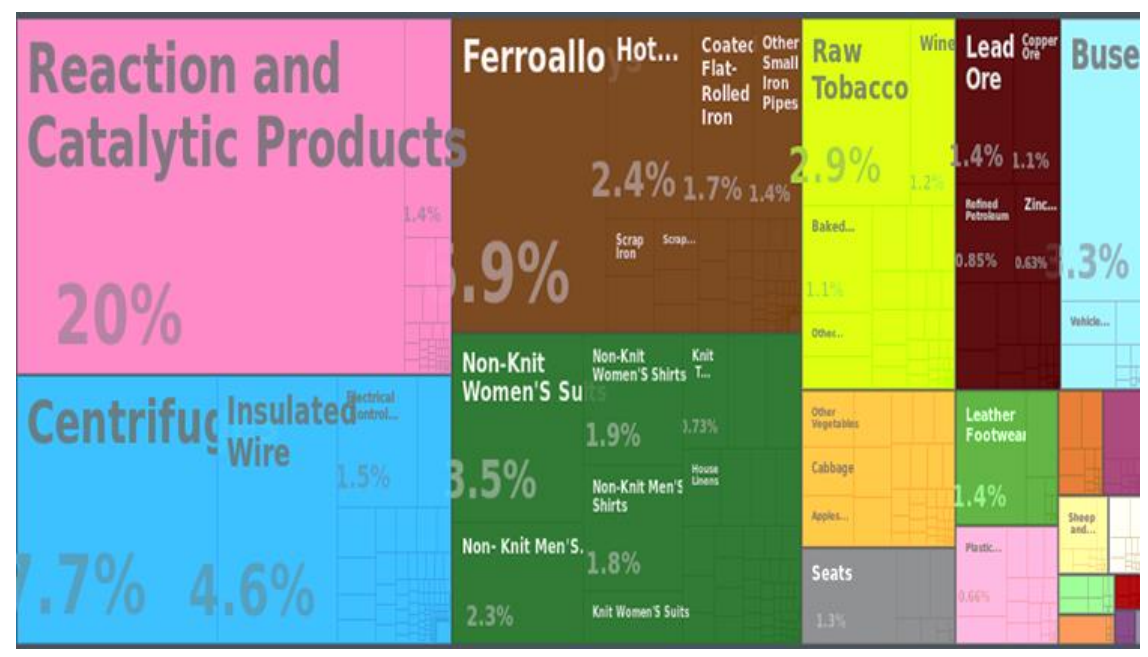

Source: Authors' calculation based on ComTrade database

The chemicals and related products are presented with the pink color. This industry (reaction and catalytic products, packaged medicaments, glaziers' putty, hydrogen, beauty products and others) with total value of 1.220 million dollars has the highest relative share (almost 22\%) in Macedonian export in 2014. The textile industry and foofwear (dark and light green color) with 954 million dollars export value are the second largest industries, while machines (blue color) dominated by centrifuges, insulated wire, electrical control boards, electrical batteries, electrical capacitors and others with 921 million dollars export value has significant impact on Macedonian export. Even though, the metal industry (marked with brown color at the product space) was severely affected by the global economic crisis it still has important role in Macedonian export. Actually, this industry exported nearly 865 million dollars, which is about $16 \%$ of the total country's export. No less important exporting sector is agricultural (vegetable products, animal products, animal and 
Lazarov D., Kocovski M.: Empirical analysis of Macedonian export structure: the role...

vegeteble bi-products, frozen vagetebles, food stuffs). The total export value of this sector (marked with dark and light yellow color) is 693.3 million dollars or almost $13 \%$ of total country's export.

Even though the total number of products that Macedonia exports with comparative advantage (calculated according to 6-digit Harmonized classification of products) has increasing trend in the last decade, the export is still not much diversified. For illustration, the country exports only 460 products with comparative advantage $(\mathrm{RCA}>1)$ from 5.107 products that are produced and exported in the world based on 6-digit HS classification system. On the other side, as the most diversified country in the world produces and exports products.

Figure 4. Macedonian product Space in 2014

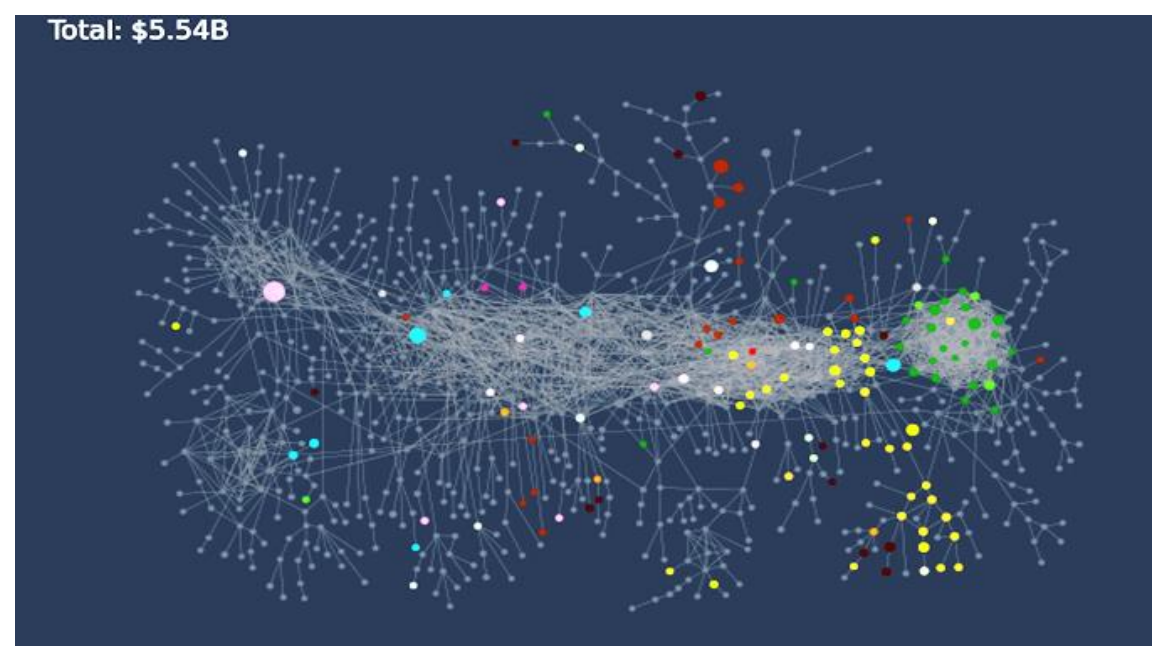

Source: Authors' calculation based on ComTrade database

The less diversified export basket makes the economy very vulnerable to external shocks. Actually, it has happened during the current global crisis where the main transmission channel of the crisis was through foreign demand. The existing empirical literature about export structure and export performance shows that export diversification has significant positive impact on export performance. In the case of Macedonia, the export diversification also has positive and significant effect on the country's export volume.

Macedonia export is not only less diversified, but it is characterizes as one of the less sophisticated in the region. To measure the export sophistication level, it has been used the EXPY idex. This index is calculated as the weighted average of the sophistication level of products exported by a country 
Lazarov D., Kocovski M.: Empirical analysis of Macedonian export structure: the role...

(PRODYK), where the weights are simply the value shares of the products in the country's total exports:

$$
E X P Y_{i}=\sum_{l}\left(\frac{x_{i l}}{X_{i}}\right) P R O D Y_{l}
$$

The average EXPY value is less than 10.000 US dollars, while almost all countries (except Albania) in the region have average EXPY more than 11.000 US \$). Moreover, Macedonia is the only country in the region which has decreasing trend of EXPY index in the analyzed period.

Figure 5. Export sophistication level (EXPY value) in the period 1997-2007

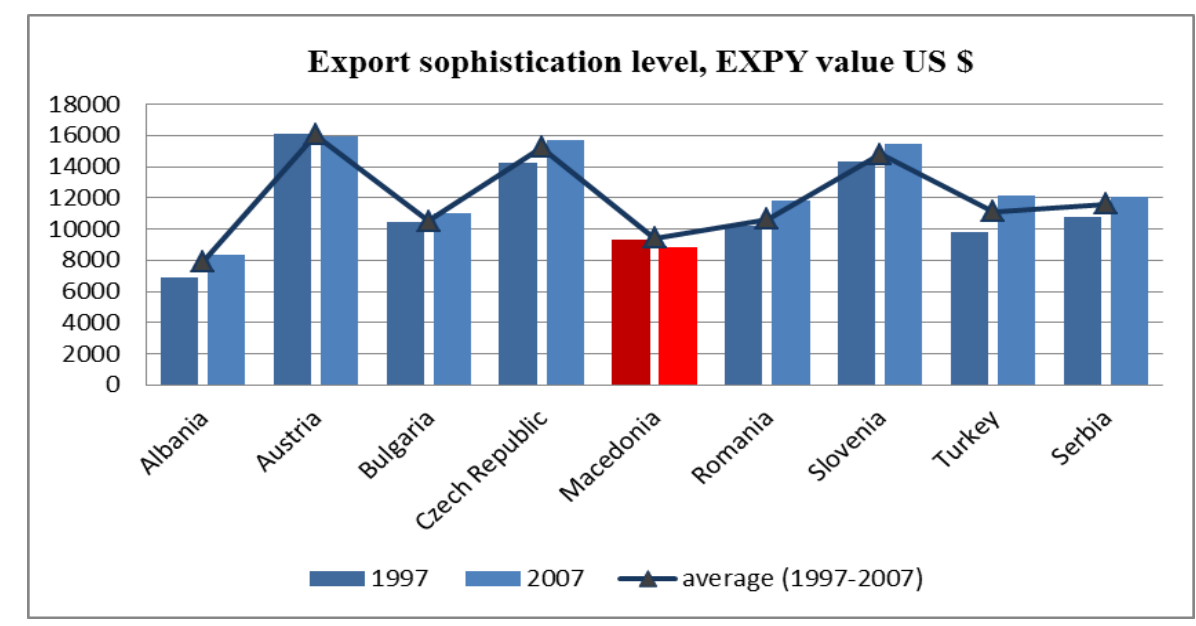

Source: Authors' calculation based on BACl database

\subsection{The metal industry exporting performance and its role in Macedonian export}

The metal industry was the biggest exporting industry in Republic of Macedonia in 1995 (391 million US dollars export values) with the relative share in total country's export of $25 \%$. The total number of metal products produced and exported with comparative advantages (RCA>0.5) in 1995 is approximately 75 (according to 6-digit HS classification system) indicating that this industry is highly diversified. 
Lazarov D., Kocovski M.: Empirical analysis of Macedonian export structure: the role...

Table 2. Top ten exported products from metal industry in 1995

\begin{tabular}{|c|c|c|c|c|c|}
\hline \# & $\begin{array}{l}\text { Product } \\
\text { Code }\end{array}$ & Product name & $\begin{array}{c}\text { Export } \\
\text { value, US } \\
\$\end{array}$ & RCA & PRODY \\
\hline 1 & 720260 & Ferronickel & 42909116 & 391.52 & 5423 \\
\hline 2 & 720842 & $\begin{array}{l}\text { Other Flat-rolled Products, Not in Coils, } \\
\text { of a thickness exceeding } 10 \mathrm{~mm}(0.39 \\
\text { inch) }\end{array}$ & 5983466 & 9.64 & 9832 \\
\hline 3 & 730660 & $\begin{array}{l}\text { Other Tubes, Pipes, Hollow Profiles, } \\
\text { welded, of non-circular cross section }\end{array}$ & 5154402 & 10.09 & 13242 \\
\hline 4 & 730719 & Other Tube or Pipe Fittings, of Cast Iron & 3327479 & 18.35 & 10494 \\
\hline 5 & 820750 & $\begin{array}{l}\text { Tools for drilling, other than for rock } \\
\text { drilling, and parts thereof: }\end{array}$ & 3018098 & 9.86 & 14512 \\
\hline 6 & 820740 & $\begin{array}{c}\text { Tools for tapping or threading, and parts } \\
\text { thereof }\end{array}$ & 3004578 & 31.85 & 11403 \\
\hline 7 & 730512 & $\begin{array}{l}\text { Other Line pipe of a kind used for oil or } \\
\text { gas pipelines, longitudinally welded }\end{array}$ & 2229051 & 31.19 & 8747 \\
\hline 8 & 731815 & $\begin{array}{l}\text { Other screws and bolts, whether or not } \\
\text { with their nuts or washers of Iron or Stee }\end{array}$ & 1373958 & 1.19 & 16259 \\
\hline 9 & 730890 & $\begin{array}{c}\text { Other Structures and Parts of Structures, } \\
\text { of Iron or Steel }\end{array}$ & 1218471 & 0.64 & 13167 \\
\hline $\begin{array}{l}1 \\
0\end{array}$ & 720843 & $\begin{array}{c}\text { Other Flat-rolled Products, Not in Coils, } \\
\text { of a thickness of } 4.75 \mathrm{~mm}(0.187 \text { inch) or } \\
\text { more but not exceeding } 10 \mathrm{~mm}(0.39 \\
\text { inch) }\end{array}$ & 1198534 & 4.16 & 9759 \\
\hline
\end{tabular}

Source: Authors' calculation based on ComTrade database

Even though total export volume of metal industry has increased from 391 in 1995 to 612 million US dollars in 2014, its relative share in country's export has decreasing trend. Also, the total number of metal products exported with comparative advantages has decreased from 75 to 55 products in 2014 . However, this industry is still one of the largest exporting industries in Republic of Macedonia (the relative share in total country's export in 2014 is $11 \%)$ and still has capacity to extended its export basket.

The export structure of metal industry changed a bit in the last decade. The most dominant exporting products are still ferroalloys, but in the top ten exporting products are no longer tools and articles from base metal. Instead, hot-rolled steel, goated flat-rolled steel, steel pipe and tubes, steel bars are now part of top ten exporting products [Table 3].

The biggest exporters are: Feni Industry, Makstil, IGM trade, Jugohrom, and Arcelor Mittal.

Regarding export destination, metal industry is diversified to several countries (China, Germany, Italy, Spain, Croatia, Greece, Serbia, United Kingdom, and France). For illustration, in the Figure 6 below we present export destination of 
Lazarov D., Kocovski M.: Empirical analysis of Macedonian export structure: the role...

ferroalloys and hot-rolled products of iron and steel as main exporting products in Republic of Macedonia.

Table 3. Top ten exported products from metal industry in 2014

\begin{tabular}{|c|c|c|c|c|c|}
\hline \# & $\begin{array}{l}\text { Product } \\
\text { Code }\end{array}$ & Product name & $\begin{array}{c}\text { Export } \\
\text { Value, US } \\
\$ \$\end{array}$ & RCA & PRODY \\
\hline 1 & 720260 & Ferronickel & 290137592 & 243.10 & 13164 \\
\hline 2 & 720221 & $\begin{array}{c}\text { Ferrosilicon Containing by weight more } \\
\text { than } 55 \text { percent of silicon; silicon } \\
\text { content }\end{array}$ & 89967444 & 93.95 & 31628 \\
\hline 3 & 720851 & $\begin{array}{l}\text { Other Flat-rolled Products of Iron or } \\
\text { Non-alloy Steel, Hot-rolled }\end{array}$ & 72654761 & 22.66 & 20886 \\
\hline 4 & 721070 & $\begin{array}{l}\text { Flat-rolled Products of Iron, Painted, } \\
\text { varnished or coated with plastics }\end{array}$ & 66358171 & 17.88 & 15238 \\
\hline 5 & 730661 & Other Tubes, Pipes, Hollow Profiles & 51026876 & 38.43 & 18046 \\
\hline 6 & 720852 & $\begin{array}{l}\text { Other Flat-rolled Products of Iron or } \\
\text { Non-alloy Steel, Hot-rolled }\end{array}$ & 48793612 & 45.67 & 19041 \\
\hline 7 & 721049 & $\begin{array}{l}\text { Other Flat-rolled Products, } \\
\text { Electrolytically Plated or Coated With } \\
\text { Zinc }\end{array}$ & 35551588 & 5.07 & 17818 \\
\hline 8 & 730630 & $\begin{array}{l}\text { Other Tubes, Pipes, Hollow Profiles, } \\
\text { welded, of circular cross section, of iron } \\
\text { or non-alloy steel }\end{array}$ & 24099956 & 13.67 & 12036 \\
\hline 9 & 720449 & Other Ferrous Waste and Scrap & 15127681 & 2.54 & 21480 \\
\hline 10 & 732189 & $\begin{array}{l}\text { Parts of Cooking Appliances, Plate } \\
\text { Warmers and Other Appliances }\end{array}$ & 14733341 & 30.66 & 26137 \\
\hline
\end{tabular}

Source: Authors' calculation based on ComTrade database

Table 6. Export destination of ferroalloys (1995 - 2014)

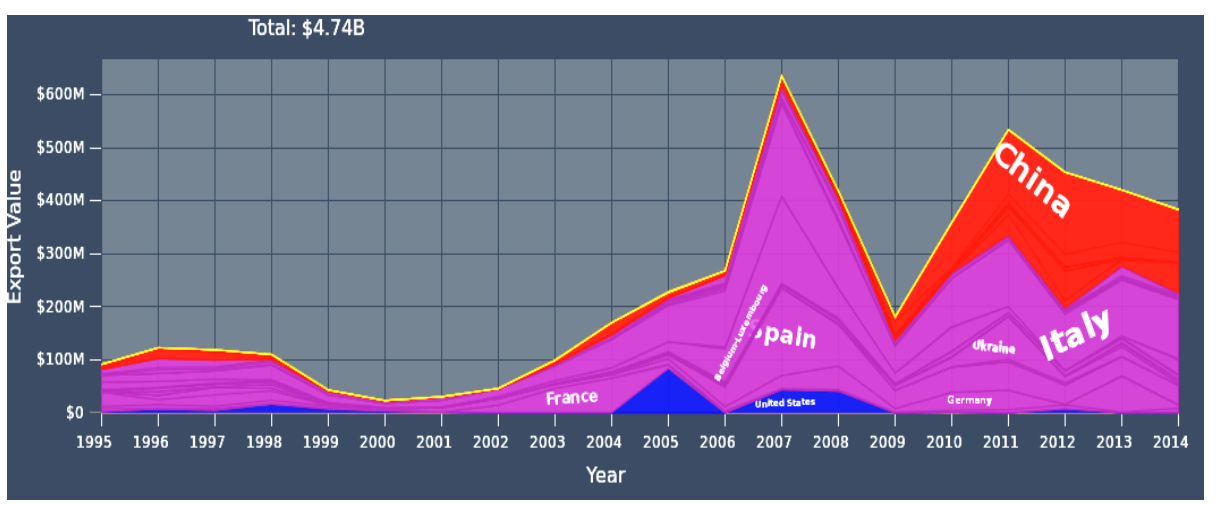

Source: Authors' calculation based on ComTrade database 
Lazarov D., Kocovski M.: Empirical analysis of Macedonian export structure: the role...

Table 7. Export destination of hot-rolled iron and steel (1995-2014)

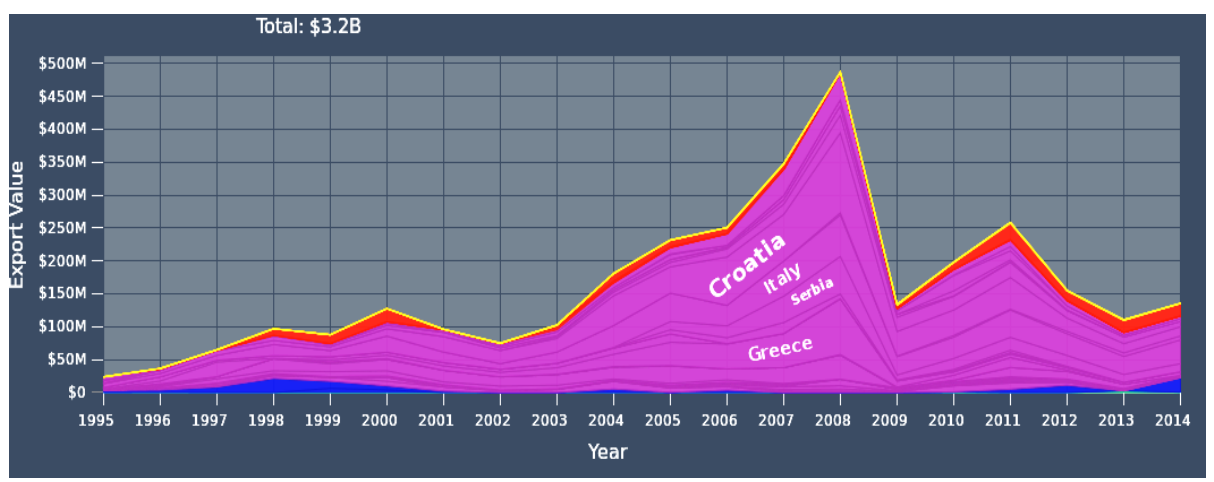

Source: Authors' calculation based on ComTrade database

More important here is the analysis of added value and complexity of each metal product that is produced and exported with comparative advantages. The product sophistication level $\left(P R O D Y_{K}\right)$ is calculated as a weighted average of the GDP per capita of countries exporting that product. The index can be presented by the following equation:

$$
\operatorname{PRODY}_{K}=\sum_{j} \frac{\left(x_{j k} / X_{j}\right)}{\sum_{j}\left(x_{j k} / X_{j}\right)} Y_{j}
$$

where, the term, $x_{j k} / X_{j}$, is the relative share of export product in the total value of country's export, while the term, $\sum_{j}\left(x_{j k} / X_{j}\right)$, is the aggregate relative share of all countries exporters of that product. So, the index represents the weighted average of the GDP per capita, where the weighted corresponded to country's comparative advantage value of exported product $k$. The estimated PRODY value for each top ten metal exporting products in 1995 and 2014 are presented in the Table 2 and Table 3 above.

The estimated average PRODY value (as a proxy variable for products complexity) for top ten exporting metal products in Macedonian export structure is 19.647 US $\$$, while the average PRODY value for top ten most sophisticated metal products is 72.950 US $\$$ indicating that Macedonian metal industry is far behind compare with most sophisticated metal exporting countries. 
Lazarov D., Kocovski M.: Empirical analysis of Macedonian export structure: the role...

\section{Concluding remarks}

The paper investigates the Macedonian export structure and export performance using several indexes: 1) export complexity- weighted average of the sophistication level of products exported by the country, 2) export diversity - number of products that country produces and exports with comparative advantages, and 3) export ubiquity - number of countries produce a same set of products. Moreover, the paper analyzes the performance of metal industry productivity as one of the most exporting industry and investigates its capacity for further product diversification. The results indicate that Macedonian export basket is highly concentrated (the top ten products have nearly half of the total country's export and more than 70 percent of the export goes to several countries) and composed of low complexed products. Additionally, the results show that export structure is less diversified, making the economy very sensitive on the external shocks. On the other side, the analysis of metal industry performance in Republic of Macedonia shows that this industry is faced with lot of problems in the last several years, but it still has comparative advantages $(R C A=2.16)$ and is characterized as medium diversified industry (55 products are exported with comparative advantages in 2014). The results of the analysis regarding to industry complexity demonstrate that this industry has strong capacity for further product diversification by building new capabilities for production of more complexed products. So, the paper suggests to policymakers in Macedonia to create an active industrial policy that will stimulate the structural transformation of metal industry by addressing the information and coordination failures and supporting the product diversification of this industry.

\section{References}

Ahmad, J., Harnhirun, S. and Yang, J. (1997) Export and economic growth in the ASEAN countries: cointegration and causality tests.International Review of Economics and Business 44, 419-30.

Balassa, B. (1965). Trade Liberalisation and "Revealed" Comparative Advantage. Manchester School, 33(2), 99-123. doi:10.1111/j.14679957.1965.tb00050.x

Chow, P.C.Y. (1987) Causality between export growth and industrial development: empirical evidence fromthe NICs. Journal of Development Economics 26, 55-63.

Darrat, A.F. (1987) Are exports an engine of growth? Another look the evidence. Applied Economics 19, 277-83.

Islam, M.N. (1998) Export expansion and economic growth: testing for cointegration and causality. Applied Economics 30, 415-25.

Islam, M.N. and Iftekharuzzaman, M. (1996) Export-growth nexus in a small open economy: the case of Bangladesh. In Weis, C.E. and Wahid, A.N.M. (eds.) The 
Lazarov D., Kocovski M.: Empirical analysis of Macedonian export structure: the role...

Economy of Bangladesh: Problems andnProspects. Westport, CT: Praeger Publishing

Jesus, F., Kumar, U., \& Abdon, A. (2010). Exports, Capabilities, and Industrial Policy in India. Working Paper, Annandale-on-Hudson, NY, 638, Levy Economics Institute of Bard College.

Liu, X., Song, H. and Romilly, P. (1997) An empirical investigation of the causal relationship between openness and economic growth in China. Applied Economics 29, 1679-86

Keesing, D..B. (1967) Outward-looking policies and economic development=. Economic Journal 77, 303-20

Krueger, A.O. (1985) The experience and lessons of Asia superexporters. In Corbo,V., Krueger, A.O. and Ossa, F. (eds.) Export-oriented Development Strategies: The Success of Five Newly Industrialized Countries. London: Westview Press

Siggell, (2007). International Competitiveness and Comparative Advantage: A Survey and a Proposal for Measurement. Center for Economic Studies / Ifo Institute. Retrieved from https://www.cesifogroup.de/portal/pls/portal/!PORTAL.wwpob page.show? docn ame $=956160$. PDF

Shan, J. and Sun, F. (1998a) Export-led growth hypothesis for Australia: an empirical re-investigation. Applied Economics Letters 5, 423-8.

Shan, J. and Sun, F. (1998b) On the export-led growth hypothesis: the econometric evidence from China. Applied Economics 30, 1055-65.

Shan, J. and Sun, F. (1998c) 'On the export-led growth hypothesis for the little dragons: an empirical reinvestigation'. Atlantic Economic Journal 26, 353-71.

Thornton, J. (1996) Cointegration, causality and export-led growth in Mexico, 18951992'. Economics Letters 50, 413-6.

Hausmann, R., Hwang, J., \& Rodrik, D. (2007). What you export matters. Journal of Economic Growth, 12(1), 1-25. doi:10.1007/s10887-006-9009-4

Hausmann, R., \& Bailey, K. (2006). Structural Transformation and Patterns of Comparative Advantage. CID Working Paper, 128, Center for International Development, Harvard University.

Hidalgo, C.A., Klinger, B., Barabási, A., \& Hausmann, R. (2007). The product space conditions the development of nations. Science, 317(5837), 482-7. pmid:17656717. doi:10.1126/science. 1144581

Hidalgo, C. (2009). The Dynamics of Economic Complexity and the Product Space Over a 42 Year Period. Center for International Development at Harvard University. Working Paper, 189, December. Harvard University.

Hidalgo, C., \& Hausmann, R. (2009). The Building Blocks of Economic Complexity. Proceedings of the National Academy of Sciences, 106(26), 10570-10575. 